\title{
CERAMIC MATERIALS LEAD TO UNDERESTIMATED DNA QUANTIFICATIONS: A METHOD FOR RELIABLE MEASUREMENTS
}

\author{
E. Piccinini ${ }^{\dagger}$, N. Sadr ${ }^{\dagger}$, and I. Martin* \\ Departments of Surgery and of Biomedicine, University Hospital Basel, Basel, Switzerland \\ $\uparrow$ These authors contributed equally to the present work
}

\begin{abstract}
In the context of investigating cell-material interactions or of material-guided generation of tissues, DNA quantification represents an elective method to precisely assess the number of cells attached or embedded within different substrates.

Nonetheless, nucleic acids are known to electrostatically bind to ceramics, a class of materials commonly employed in orthopaedic implants and bone tissue engineering scaffolds. This phenomenon is expected to lead to a relevant underestimation of the DNA amount, resulting in erroneous experimental readouts. The present work aims at (i) investigating the effects of DNA-ceramic bond occurrence on DNA quantification, and (ii) developing a method to reliably extract and accurately quantify DNA in ceramiccontaining specimens.

A cell-free model was adopted to study DNA-ceramic binding, highlighting an evident DNA loss (up to 90\%) over a wide range of DNA/ceramic ratios (w/w). A phosphate buffer-based $(800 \mathrm{mM})$ enzymatic extraction protocol was developed and its efficacy in terms of reliable DNA extraction and measurement was confirmed with commonly used fluorometric assays, for various ceramic substrates. The proposed buffered DNA extraction technique was validated in a cell-based experiment showing 95\% DNA retrieval in a cell seeding experiment, demonstrating a 3.5-fold increase in measured DNA amount as compared to a conventional enzymatic extraction protocol.

In conclusion, the proposed phosphate buffer method consistently improves the DNA extraction process assuring unbiased analysis of samples and allowing accurate and sensitive cell number quantification on ceramic containing substrates.
\end{abstract}

Keywords: DNA extraction, DNA quantification, ceramic, tissue engineering.

\footnotetext{
*Address for correspondence:

Ivan Martin

Institute for Surgical Research and Hospital Management University Hospital Basel

Hebelstrasse 20, ZLF, Room 405

CH-4031 Basel, Switzerland

Telephone Number: +41612652384

FAX Number: +41612653990

E-mail: imartin@uhbs.ch
}

The development of tissue engineering (TE) approaches and biomedical implant substrates often requires assessments of cell-material and tissue-material interactions. For example, the most typically adopted cellbased TE approaches rely on efficient seeding, proliferation and differentiation of cells on threedimensional substrates (scaffolds) in order to obtain a biological graft. Among these substrates, ceramic based scaffolds have been widely investigated for bone TE (BTE) (Hutmacher et al., 2007; Rezwan et al., 2006; Salgado et al., 2004). In fact, this class of materials resembles the mineral fraction of the bone extracellular matrix (ECM), which is known to have a role in actively guiding bone progenitor differentiation (Gigante et al., 2008; Lin et al., 2009). Based on this evidence, many studies have been focused on evaluating either different chemical compositions or different architectural arrangements targeting an improved BTE scaffold design (Karageorgiou and Kaplan, 2005; Khan et al., 2008; Liu et al., 2008; Stevens et al., 2008). A significant portion of these studies relies on the in vitro investigation of cellmaterial interactions ultimately analysing cell adhesion, proliferation and differentiation.

Deoxyribonucleic acid (DNA) quantification is a routine assay of crucial value when performing studies based on accurate evaluation of cell number. Indeed, the high sensitivity and accuracy of available techniques offers consistent advantages as compared to metabolic based assays for cell viability. In fact, viability readouts lean on cell metabolic activity, which could vary depending on time and cell culture conditions, thus possibly hampering an unambiguous correlation with actual cell number.

It is therefore clear that DNA-based methods have a prominent role whenever cell adhesion/proliferation experiments (DNA being the parameter of interest) or cell differentiation experiments (DNA being the term of normalization for other assays, e.g. enzymatic activity or protein expression) are performed in order to investigate cell-material interactions. Mostly based on enzymatic digestion (Cui et al., 2007; Gilbert et al., 2009; Liu et al., 2008) and chemical or mechanical cell lysis (Du et al., 2008; Kotobuki et al., 2006), DNA quantification relies on homogeneously dispersing the total amount of DNA in the assayed extraction solution; thus, it is crucial to consider possible flaws arising from chemo-physical processes occurring during the extraction procedure.

In this context, it is often neglected that ceramic materials reversibly bind nucleic acids (NAs) through polar interactions. This phenomenon, that is routinely 
exploited in chromatographic columns, is caused by the interactions between positive charges of the ceramic material (mainly $\mathrm{Ca}^{2+}$ and partially positive $\mathrm{H}$ of $\mathrm{OH}$ groups) and negative charges of phosphate groups of NAs (Giovannini and Freitag, 2000). The occurring electrochemical bond is reversible and the NAs are eluted from the ceramic stationary phase by means of phosphate buffers (Watanabe et al., 1999). The chemical interactions of NAs and ceramic surfaces could potentially interfere with DNA measurements while performing cell-material studies. The binding would indeed result in a depletion of DNA from the extracting solution and eventually in an erroneous quantification of its amount.

The present work aims at (i) investigating the impact of DNA-ceramic bond occurrence on precise DNA quantification, and (ii) developing a reliable DNA extraction technique to overcome the limitations of traditional protocols. The proposed method is intended to enhance the accuracy of available assays, assuring reliable DNA extraction and quantification in those experiments which ultimately rely on DNA content measurements to evaluate cell adhesion, proliferation and differentiation on ceramic based substrates.

\section{Materials and Methods}

\section{Experimental models}

In the present work, two different experimental models were adopted: a simplified cell-free model based on purified DNA and a conventional cell-based model. The former, that avoids the variability related to handling cells, allows reproducible sample preparation with defined DNA amounts and was used to: (i) test the hypothesis of erroneous DNA quantification due to DNA-ceramic binding; (ii) compare enzymatic digestion and mechanic disruption as methods for DNA extraction; and (iii) evaluate protocol applicability to different ceramic compounds and routinely used DNA assays. The cell-based model was exploited to validate the protocol in a typical cell-material study setup.

In the simplified cell-free model, in order to emulate cell number analysis on a ceramic material, stock DNA solutions at known concentrations (hereafter referred as stock solutions) were used to soak ceramic substrates (the solution in contact with the substrates will be hereafter referred to as soaking solution). DNA amounts in both stock solution and soaking solution were measured at defined time points. The ratio between DNA amount in the soaking solution and the stock solution was defined as the efficiency of DNA retrieval.

In the cell-based model, a known number of cells was statically seeded on a ceramic substrate (Wendt et al., 2003). Total amount of DNA was measured either overnight or after two weeks culture and compared with DNA extracted from a corresponding number of cells frozen immediately prior to seeding.

\section{Ceramic substrates}

Three different granular ceramic substrates (bone graft substitutes) were assessed in the simplified cell-free model:
chronOS ${ }^{\mathrm{TM}}$ (b-tricalcium phosphate, porosity $60 \%, 1.4$ $2.4 \mathrm{~mm}$; Synthes ${ }^{\circledR}$, West Chester, PA, USA), Skelite ${ }^{\mathrm{TM}}$ (67\% silicon stabilized tricalcium phosphate, 33\% hydroxyapatite, porosity $65 \%$, granules $3-3.2 \mathrm{~mm}$, single cylindrical granule 3.9-4.1 mm thickness x 5-5.5 mm diameter; Octane Orthobiologics, Kingston, Ont., Canada), and ENGIpore (pure hydroxyapatite, porosity 83\%, 0.5$1 \mathrm{~mm}$; Finceramica, Faenza, Italy). Unless otherwise stated, chronOSTM granules were used. For the cell-based experiment, Skelite ${ }^{\mathrm{TM}}$ scaffolds with the same bulk chemical composition of the granules used in the simplified cell-free model, but in the shape of single cylindrical granule with an adequate size for static cell seeding, were adopted.

\section{Cell source and culture}

Bone marrow aspirates (20 ml volumes) were obtained from the iliac crest of a healthy donor during routine orthopaedic surgical procedures, in accordance with the local ethical committee (University Hospital Basel) and subsequent to informed consent. Following expansion, $2 * 10^{4}$ cells/scaffold were statically seeded on each ceramic scaffold in agarose coated 12 well-plates. Samples with identical cell numbers were frozen in order to be used as DNA reference. The efficiency of the method was calculated based on the ratio between the DNA amount measured on the scaffold and the DNA amount measured in reference samples containing a number of cells equal to that seeded on each scaffold (Wendt et al., 2003).

After 16 hours from seeding, the scaffolds were either collected for DNA quantification or transferred in new wells for a total of 14 days culture. The bottom of the wells was microscopically inspected after the seeding and during the culture, assessing that only a negligible number of cells did not adhere on the scaffold upon seeding.

Cell culture was carried out in complete medium (CM, $\alpha$-Modified Eagle's Medium, 10\% foetal bovine serum, HEPES buffer solution $100 \mathrm{mM}$, sodium pyruvate $1 \mathrm{mM}$, penicillin $100 \mathrm{U} / \mathrm{ml}$, streptomycin $100 \mu \mathrm{g} / \mathrm{ml}$ and $292 \mu \mathrm{g} /$ ml L-glutamine; Gibco Invitrogen, Basel, Switzerland) supplemented with $10 \mathrm{nM}$ dexamethasone, $10 \mathrm{mM} \beta$ glycerophosphate, and $0.1 \mathrm{mM}$ ascorbic acid-2-phosphate. This composition is known to induce hMSCs osteogenic differentiation and to favour mineralized extracellular matrix (ECM) deposition (Bancroft et al., 2002).

\section{Extraction methods}

DNA amount measurements in biological specimens typically rely on an extraction step to destroy cell membranes and ECM and homogeneously disperse DNA in the aqueous solution. In the present work, a proteinase $\mathrm{K}$ solution ( $\mathrm{pK}$; prepared adding proteinase $\mathrm{K} 1 \mathrm{mg} / \mathrm{ml}$, pepstatin A $10 \mu \mathrm{g} / \mathrm{ml}$, EDTA $1 \mathrm{mM}$, iodoacetamide $1 \mathrm{mM}$, TRIS $50 \mathrm{mM}$ to distilled water; Sigma-Aldrich, St. Louis, MO, USA) was adopted to enzymatically digest the samples for 16 hours at $56^{\circ} \mathrm{C}$ (Hollander et al., 1994).

To assess the degree of DNA underestimation due to DNA-ceramic binding, foetal calf thymus DNA (SigmaAldrich) was diluted at different concentrations $(0,2,5$, $10,20,80,160,320 \mu \mathrm{g} / \mathrm{ml})$ in $\mathrm{pK}$ solutions. A fixed volume $(300 \mu \mathrm{l})$ of each DNA stock solution was transferred in 
Eppendorf (Hamburg, Germany) tubes containing $0.16 \pm$ $0.003 \mathrm{~g}$ of ceramic granules. Subsequently, the stock solutions and the soaking solutions were incubated at $56^{\circ} \mathrm{C}$ and assayed after 16 hours, to simulate an overnight digestion.

With the purpose of inhibiting DNA-ceramic binding, phosphate buffered extraction solutions (PpK) were obtained supplementing $\mathrm{pK}$ solutions with potassium phosphate salts $\left(\mathrm{HK}_{2} \mathrm{PO}_{4}\right.$ and $\mathrm{H}_{2} \mathrm{KPO}_{4}$; Fluka; SigmaAldrich). Since it is known that the elution efficacy depends on the ionic strength of the solution and is effective only over a critical value that is correlated to several factors such as ceramic composition, salt ions, and $\mathrm{pH}$ (Chen et al., 2007; Milligan et al., 1987), different phosphate concentrations ( $400 \mathrm{mM}, 600 \mathrm{mM}$, and $800 \mathrm{mM}$; pH 6.5) were assayed.

Commercially available Phosphate Buffer Solution (PBS, 4 mM, pH 7.2, Gibco Invitrogen) and non-buffered $\mathrm{pK}$ solution were adopted as negative controls.

As an alternative extraction method, mechanical disruption of cellular structure was tested. Within this method a potassium phosphate buffered solution $(\mathrm{P})$ was adopted in absence of $\mathrm{pK}$ and coupled with sonication. The $\mathrm{P}$ solution was prepared adding $\mathrm{HK}_{2} \mathrm{PO}_{4}$ and $\mathrm{H}_{2} \mathrm{KPO}_{4}$ (final phosphate concentration $800 \mathrm{mM}$; $\mathrm{pH}$ 6.5), EDTA (1 $\mathrm{mM})$ to distilled water.

$\mathrm{PpK}, \mathrm{PBS}, \mathrm{pK}$ and $\mathrm{P}$, prepared as described in the previous paragraphs, were supplemented with foetal calf thymus DNA $(1 \mu \mathrm{g} / \mathrm{ml})$. Aliquots of DNA stock solutions $(300 \mu \mathrm{l})$ were transferred in Eppendorf tubes containing the ceramic granules.

In order to mimic enzymatic digestion, $\mathrm{PpK}$ and $\mathrm{pK}$ samples were incubated overnight at $56^{\circ} \mathrm{C}$. On the other side, to resemble mechanical disruption, $\mathrm{P}$ samples were sonicated in a Sonic Dismembrator 550 (Thermo Fisher Scientific, Waltham, MA, USA) for 5 minutes. Sonicated samples were stored at room temperature. Aliquots of each stock solution were maintained either in the same chemophysical conditions of the corresponding soaking solution or frozen at $-20^{\circ} \mathrm{C}$ and thawed immediately before each DNA measurement performed after 1 hour and 16 hours.

For the cell-based model, the number of cells seeded on each scaffold $(0.08 \pm 0.005 \mathrm{~g})$ was chosen so as to approximately maintain the DNA/ceramic (w/w) ratio adopted in the simplified cell-free model as described in the previous paragraph. An approximate value of $7.5 \mathrm{pg}$ of DNA per cell for expanded hMSCs was adopted based on mean values obtained assaying known numbers of cells in previous experiments.

Samples collected 16 hours (overnight) and 14 days after seeding were immediately frozen and stored at $-20^{\circ} \mathrm{C}$ till the measurement. Cultured specimens and defined cell numbers were digested for 16 hours in $150 \mu$ l of either $\mathrm{pK}$ or PpK ( $800 \mathrm{mM})$ before being analysed.

All the experiments described above were run in triplicate for each experimental group.

\section{Enzymatic activity}

Since it is known that high saline concentrations could lead to enzyme inactivation, the ability of proteinase $\mathrm{K}$ to digest collagen fibres, representative of cell deposited
ECM, was qualitatively assessed in the presence of potassium phosphate. Discs $(6 \mathrm{~mm}$ diameter, $3 \mathrm{~mm}$ thickness) punched from sterile sheets of Ultrafoam ${ }^{\mathrm{TM}}$ collagen hemostat (Davol, Warwick, RI, USA) were soaked in PpK (800 mM), P (800 mM), pK or distilled water. Samples were incubated at $56^{\circ} \mathrm{C}$ for 16 hours. Collagen sponge integrity was finally assessed by visual inspection.

\section{DNA quantification}

DNA quantification was performed by means of a commercially available fluorescence based kit, namely CyQUANT $^{\circledR}$ Cell Proliferation Assay (Invitrogen ${ }^{\circledR}$ ). Working solutions were prepared according to the manufacturer's protocols.

As alternative methods, Quant-iT ${ }^{\mathrm{TM}}$ PicoGreen $^{\circledR}$ dsDNA Kit (Invitrogen ${ }^{\circledR}$ ) and a Hoechst-based assay (Hoechst $333420.2 \mu \mathrm{g} / \mathrm{ml}, 10 \mathrm{mM}$ Tris- $\mathrm{HCl}, 1 \mathrm{mM}$ EDTA, $200 \mathrm{mM} \mathrm{NaCl}, \mathrm{pH}$ 7.5; Sigma) (Barrias et al., 2005) were tested.

The analyses were carried out by adding $20 \mu \mathrm{l}$ from each sample to $180 \mu \mathrm{l}$ of working solution in black flatbottom 96 well plates, and measuring fluorescence with a Spectra Max Gemini XS Microplate Spectrofluorometer (Molecular Devices, Sunnyvale, CA, USA).

Excitation and emission wavelengths were respectively $485 \mathrm{~nm}$ and $538 \mathrm{~nm}$ for CyQUANT ${ }^{\circledR}$ and PicoGreen ${ }^{\circledR}$, or $360 \mathrm{~nm}$ and $465 \mathrm{~nm}$ for Hoechst. Samples in each plate included a calibration curve. Each sample was measured in triplicate. Unless otherwise stated, CyQUANT ${ }^{\circledR}$ was used to quantify DNA content.

\section{Results and Discussion}

The hypothesis of a DNA underestimation occurring while assaying biological samples containing ceramic materials was validated in the simplified cell-free model. DNA retrieval efficiency from ceramic materials was quantitatively evaluated in $\mathrm{pK}$ solutions prepared at different DNA concentrations. The DNA depletion phenomenon at different DNA concentrations was analysed using a fixed amount of granules to simulate different DNA-ceramic ratios. Fig. 1 shows an asymptotic retrieval curve that, even if approaching values close to $90 \%$ at the highest tested DNA concentration $(320 \mu \mathrm{g} /$ $\mathrm{ml})$, resulted in a maximum of $60 \%$ retrieval in the soaking solutions prepared at $20 \mu \mathrm{g} / \mathrm{ml}$. For values lower than 20 $\mu \mathrm{g} / \mathrm{ml}$, the retrievals nearly linearly depended on the initial DNA concentration, with the smallest DNA amount $(2 \mu \mathrm{g} /$ $\mathrm{ml}$ ) resulting in retrieval lower than $10 \%$. These data confirm that DNA measurements in presence of ceramic materials are typically affected by underestimation of the actual DNA content and that, in fact, the binding phenomenon is effective on a wide range of DNA/ceramic ratios. Noticeably, the quantification error is more relevant at lower DNA/ceramic ratios, which would be related to conditions with small cell numbers on a ceramic substrate. Indeed, coherently with our experimental conditions (DNA concentrations and total solution volume) and taking into consideration the adopted mean value of DNA per cell, 


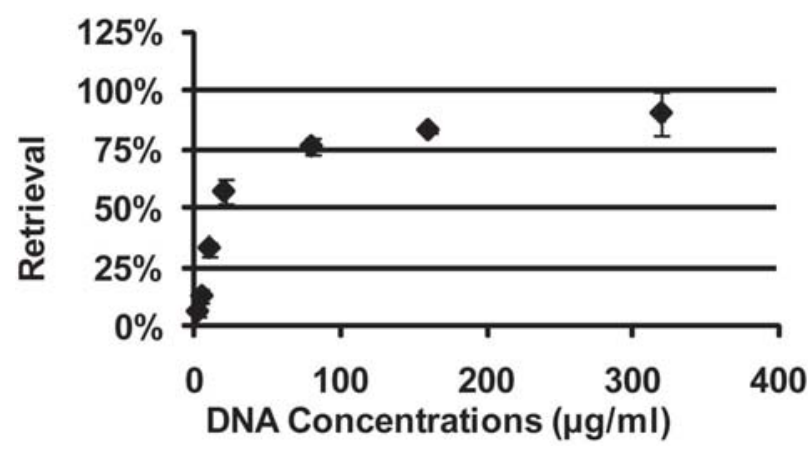

Fig. 1. DNA retrieval at different DNA concentrations: DNA retrieval efficiency was defined as DNA measured in solution after contact with granules divided by the DNA measured before contact with granules. The DNA retrieval was calculated for solutions prepared at different initial DNA concentrations $(2-320 \mu \mathrm{g} / \mathrm{ml})$. The calculated asymptotic retrieval curve evidenced consistent DNA depletion in the range of values investigated, the amount of which depended on DNA concentration in the initial solution. Under $20 \mu \mathrm{g} / \mathrm{ml}$ an approximated linear decrease was evidenced with the lowest DNA concentration $(2 \mu \mathrm{g} / \mathrm{ml})$, representative of small cell numbers, resulting in an efficiency below $10 \%$.

the evaluated DNA concentrations would be representative of a cell number ranging from $8 * 10^{4}$ to $12.8^{*} 10^{6}$ cells. It is important to consider these calculated cell numbers as rough references, taking into account that the actual DNA content per cell may change considerably based on the cell source.

With the purpose of identifying a reliable method for DNA extraction, enzymatic digestion and mechanical disruption in phosphate buffered solutions were assessed and compared to those in $\mathrm{pK}$ and PBS (all solutions prepared at $1 \mu \mathrm{g} / \mathrm{ml}$ DNA). Table 1 indicates that PBS did not prevent the binding of DNA to the ceramic material, possibly because of the low concentration of phosphate salts $(4 \mathrm{mM})$. The DNA adsorption on ceramic surfaces was proved to be reversible, since ceramic granules rinsed with $\mathrm{P}$ after removing PBS released an amount of DNA corresponding to the percentage missing in PBS (data not shown).

Similarly to PBS, the recovery of DNA in pK was only about $10 \%$ after 16 hours. Interestingly, a significant reduction in DNA retrieval was observed from 1 hour to 16 hours in $\mathrm{pK}$ (from $72 \%$ to $10 \%$ ) and PBS (from $57 \%$ to $0.5 \%$ ). This effect could be related to the time dependent infiltration of the solution and diffusion of the DNA into the complex porous structure of the ceramic material.

The depletion and the reversible release of DNA were consistent with the hypothesis of a DNA binding phenomenon based on affinity interactions typically occurring in ion-exchange chromatography columns, where the increase of the ionic strength of the mobile phase (phosphate solution) causes the release of the analytes (the DNA) from the stationary phase (ceramic granules).

Regarding the mechanical disruption protocol, the combination of sonication and $\mathrm{P}$ provided partial DNA retrieval both after 1 hour (83\%) and 16 hours (61\%), with a marked DNA loss between the two time points. The analysis of stock solutions, either maintained in the same chemo-physical conditions or frozen at $-20^{\circ} \mathrm{C}$, highlighted a detrimental effect of the mechanical disruption protocol on DNA measurement. Indeed, analysis of frozen stock solutions pointed out steady values among time points while the stock solutions maintained at room temperature displayed a decrease of DNA content over time (within each sonicated or non-sonicated group); moreover, a lower DNA content in sonicated samples compared to nonsonicated stock solutions was observed (data not shown). These observations suggest the possible occurrence of two distinct phenomena: (i) a hindering of the measurement due to DNA fragmentation caused by sonication, and/or (ii) a time related degradation of DNA at room temperature.

On the other hand, PpK provided recoveries close to $100 \%$ both after $1 \mathrm{~h}$ and $16 \mathrm{~h}$, thus showing the ability of inhibiting the DNA binding on ceramic surfaces and guaranteeing in the meantime sample stability. No differences were evident among different phosphate buffer solutions confirming that concentrations as low as $400 \mathrm{mM}$ were effective in preventing DNA-ceramic binding.

The possible inhibiting effect of high saline concentrations on the enzymatic activity of proteinase $\mathrm{K}$ was qualitatively assessed in the presence of potassium phosphate salts. Maintenance of a relevant functionality of PpK solutions $(800 \mathrm{mM})$ was confirmed by its capacity to completely dissolve, similarly to $\mathrm{pK}$, collagen scaffolds incubated at $56^{\circ} \mathrm{C}$ within $16 \mathrm{~h}$. The same scaffolds were substantially undigested if incubated in water or in 800 $\mathrm{mM}$ P. These evidences support the concept of using a high phosphate concentration $(800 \mathrm{mM})$ in order to overcome the unpredictable dilution affecting the extracting solution while assaying wet biological samples. Indeed, the undefined amount of water contained in these samples could potentially lead to a drop of phosphate concentration under the efficacy threshold.

Based on the results presented in the previous paragraphs, the enzymatic digestion extraction protocol

Table 1. DNA retrieval in different solutions: different solutions with the same initial amount of DNA $(1 \mu \mathrm{g} /$ $\mathrm{ml}$ ) were compared in terms of retrieval efficiency. Retrievals in $\mathrm{pK}$ and PBS were lower when compared to $\mathrm{P}$ and $\mathrm{PpK}$. A marked reduction of DNA retrieval after 16 hours further decreased the efficiency for $\mathrm{pK}$ and PBS. Sonicated specimens (P) displayed lower efficiency values than PpK samples that showed a complete retrieval at both time points.

\begin{tabular}{lccc}
\hline & $\begin{array}{c}\text { Phosphate } \\
(\mathrm{mM})\end{array}$ & $\begin{array}{c}\text { 1 Hour } \\
(\text { Mean } \pm \text { St. Dev })\end{array}$ & $\begin{array}{c}\text { 16 Hour } \\
(\text { Mean } \pm \text { St. Dev })\end{array}$ \\
\hline pK & - & $72.11 \pm 3.37$ & $10.86 \pm 1.11$ \\
\hline PBS & 4 & $57.63 \pm 1.77$ & $0.49 \pm 0.5$ \\
\hline P & 800 & $83.88 \pm 10.86$ & $61.24 \pm 6.62$ \\
\hline PpK & 400 & $109.87 \pm 12.06$ & $100.23 \pm 12.12$ \\
\hline PpK & 600 & $105.42 \pm 2.92$ & $99.44 \pm 0.12$ \\
\hline PpK & 800 & $102.56 \pm 2.15$ & $98.36 \pm 0.88$ \\
\hline
\end{tabular}




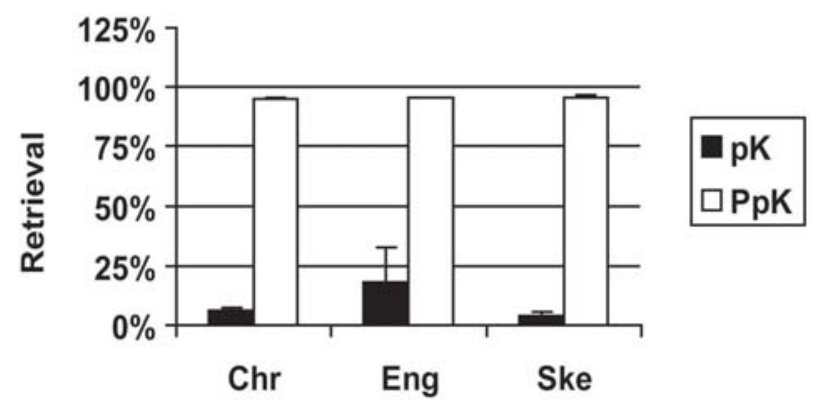

Substrates

Fig. 2. DNA retrieval with different substrates: DNA retrieval was calculated for buffered PpK (800 mM) and $\mathrm{pK}$ following the contact with three different ceramic substrates: Chr (chronOS ${ }^{\mathrm{TM}}$ ), Eng (ENGIpore), Ske $\left(\right.$ Skelite $\left.^{\mathrm{TM}}\right)$. Independently from the substrate, PpK displayed a complete DNA retrieval, while $\mathrm{pK}$ was characterized by retrieval lower than $20 \%$ with all the substrates.

at $800 \mathrm{mM}$ phosphate concentration was selected for the subsequent experiments aiming at evaluating protocol applicability to different ceramic compounds and routinely used DNA assays.

Aiming at evaluating if the extraction buffer could be adopted as an established reliable method independently from the ceramic substrate, the PpK (800 mM) was tested with three ceramic compositions, as described in the materials and methods. These compounds were chosen in order to be representative of some typical compositions used for BTE scaffolds. The results, displayed in Fig. 2, show that PpK guaranteed more than $95 \%$ retrievals with all the tested materials.

Beside different substrates, in order to evaluate the adaptability of the proposed method to most commonly used laboratory protocols for DNA quantification, PpK was tested with three different assays as described in the materials and methods. The results, shown in Fig. 3, confirmed that the extraction protocol efficiency was close to $100 \%$ with both CyQUANT ${ }^{\circledR}$ and PicoGreen ${ }^{\circledR}$, whereas Hoechst measurements were influenced by instability of the dye, thus affecting both calibration curve and sample measurements.

As a final validation test, the $\mathrm{PpK}$ based protocol was exploited in a conventional cell seeding \& culture experiment, commonly employed in cell-material in vitro studies. In light of the demonstration in the simplified cellfree model that the DNA binding and elution was independent from the type of scaffold material used, only Skelite ${ }^{\mathrm{TM}}$ scaffolds were employed for the cell-based model.

Each scaffold was seeded with $2 * 10^{4}$ cells so as to approximately maintain the DNA/ceramic (w/w) ratio adopted in the previous experiments. Samples cultured overnight or 14 days on ceramic scaffolds were digested with $\mathrm{pK}$ or PpK before DNA quantification. Fig. 4 shows that after an overnight culture the mean retrieval with $\mathrm{pK}$ was $27 \%$, while assayed $95 \%$ with $\mathrm{PpK}$, corresponding to a 3.5-fold higher extraction efficiency. Reference DNA samples, obtained by assaying cell numbers equivalent to

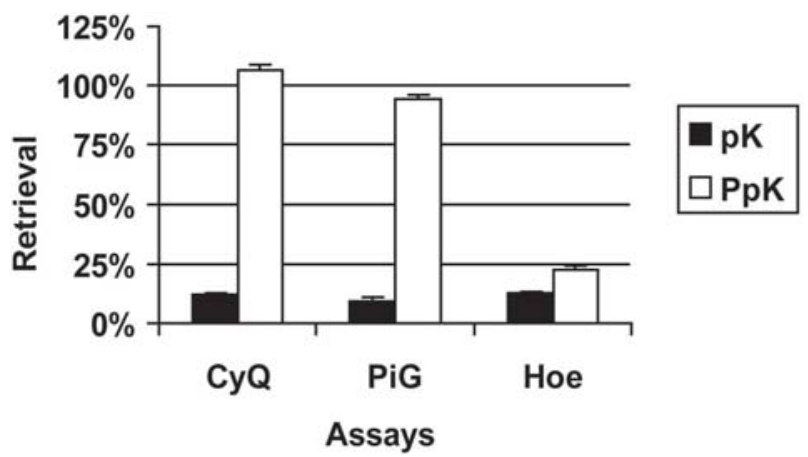

Fig. 3. DNA retrieval measured by means of different assays. DNA amount in solution was measured before and after contact with ceramic granules by means of different fluorometric assays: CyQ $\left(\mathrm{CyQUANT}^{\circledR}\right), \mathrm{PiG}$ $\left(\right.$ PicoGreen $\left.^{\circledR}\right)$, Hoe (Hoechst). The calculated retrievals for PpK were close to $100 \%$ for both CyQUANT ${ }^{\circledR}$ and PicoGreen ${ }^{\circledR}$ measurements, while those calculated for pK were systematically below $20 \%$. The same samples assayed by means of Hoechst showed low DNA amounts, resulting in low calculated retrieval for both $\mathrm{PpK}$ and $\mathrm{pK}$.

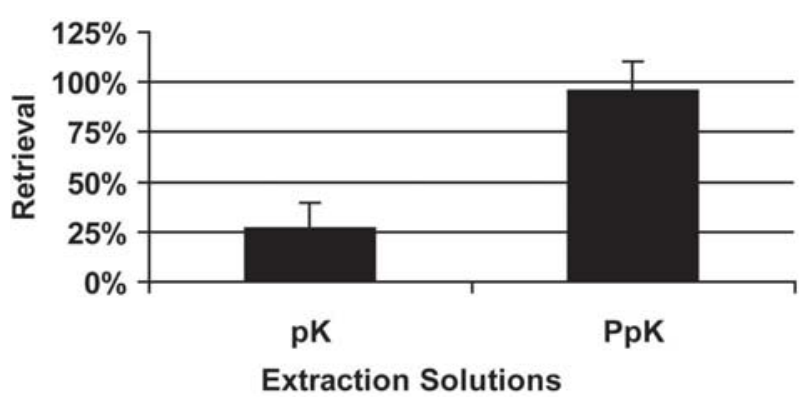

Fig. 4. DNA retrieval in a cell-based model: DNA content was measured 16 hours after seeding on samples containing a reference amount of human mesenchymal stromal cells. DNA was extracted by means of 16 hours digestion either in buffered (PpK) or non buffered $(\mathrm{pK})$ proteinase $\mathrm{K}$ solution subsequently to a freeze/thaw step. DNA retrievals calculated for $\mathrm{PpK}$ treated samples were close to $100 \%$, while the DNA amounts measured on samples treated with $\mathrm{pK}$ were close to $20 \%$ of the reference.

those seeded on ceramic substrates, did not display significant differences when digested by means of $\mathrm{pK}$ or PpK. Specimens were tested after 14 days of culture in osteogenic medium, which was assumed as a model for a cell differentiation experiment towards the osteogenic lineage, including ECM deposition. Similarly to the early time point, a 4.3-fold higher DNA quantity was revealed by means of PpK (225.6 $\pm 51.3 \mathrm{ng})$ as compared to $\mathrm{pK}$ $(52.4 \pm 38.0 \mathrm{ng})$. The data after 14-days culture cannot support the hypothesis of a complete DNA retrieval. In fact, an unknown cell proliferation and the lack of standardized quantification methods, make it difficult to compare the acquired data with a reference value. However, a higher DNA recovery and the previous evidence that proteinase $\mathrm{K}$ maintained its proteolitic properties strongly suggest that the use of PpK brings at least to an improved approximation of the DNA content in ECM-containing, long-term-culture samples. 


\section{Conclusions}

In the present work, the efficiency of DNA quantification in the presence of ceramic substrates was evaluated, pointing out a DNA-ceramic binding occurrence that could compromise accurate assays in cell-material interaction studies. The phenomenon remarkably compromised DNA measurements in a wide range of DNA/ceramic (w/w) ratio, and was more marked with small DNA amounts, representative of low cell numbers. Based on these evidences, a DNA extraction method using a phosphate buffer was developed to overcome this limitation and obtain reliable quantifications with mostly used fluorometric assays, independently from the ceramic substrate. The proposed technique guaranteed the inhibition of DNA-ceramic binding and allowed more accurate DNA retrieval, compared to traditional extraction methods, even when analyzing small DNA amounts. Moreover, the samples were stable over time, thus permitting repetitive analyses and sample storage. The overall results demonstrate that the proposed extraction protocol consistently improves the accuracy of the measurements and could therefore represent a valuable tool for those studies relying on DNA quantification on ceramic substrates, such as BTE scaffold or implant material evaluation.

\section{Acknowledgements}

The authors would like to thank Stefania Adele Riboldi for her very helpful observations and suggestions at the early stage of the present work. Ceramic materials were kindly provided by Roberta Martinetti (Fin-Ceramica Faenza S.p.A.), Timothy Smith (Octane Inc.) and Mike Lehmicke (Synthes ${ }^{\circledR}$ ). The present work was partially funded by the Swiss Commission for Technology and Innovation (CTI Nr. 7445.2 LSPP-LS).

\section{References}

Bancroft GN, Sikavitsas VI, van den Dolder J, Sheffield TL, Ambrose CG, Jansen JA, Mikos AG (2002) Fluid flow increases mineralized matrix deposition in $3 \mathrm{~d}$ perfusion culture of marrow stromal osteoblasts in a dose-dependent manner. Proc Natl Acad Sci U S A 99: 12600-12605.

Barrias CC, Ribeiro CC, Lamghari M, Miranda CS, Barbosa M,A. (2005) Proliferation, activity, and osteogenic differentiation of bone marrow stromal cells cultured on calcium titanium phosphate microspheres. J Biomed Mater Res 72A: 57-66.

Chen W-Y, Lin M-S, Lin P-H, Tasi P-S, Chang Y, Yamamoto S (2007) Studies of the interaction mechanism between single strand and double-strand DNA with hydroxyapatite by microcalorimetry and isotherm measurements. Coll Surf A: Physicochem Eng Asp 295: 274-283.

Cui L, Liu B, Liu G, Zhang W, Cen L, Sun J, Yin S, Liu W, Cao Y (2007) Repair of cranial bone defects with adipose derived stem cells and coral scaffold in a canine model. Biomaterials 28: 5477-5486.

Du D, Furukawa K, Ushida T (2008) Oscillatory perfusion seeding and culturing of osteoblast-like cells on porous beta-tricalcium phosphate scaffolds. J Biomed Mater Res Part A 86A: 796-803.

Gigante A, Manzotti S, Bevilacqua C, Orciani M, Di Primio R, Mattioli-Belmonte M (2008) Adult mesenchymal stem cells for bone and cartilage engineering: Effect of scaffold materials. Eur J Histochem 52: 169-174.

Gilbert TW, Freund JM, Badylak SF (2009) Quantification of DNA in biologic scaffold materials. J Surg Res 152: 135-139.

Giovannini R, Freitag R (2000) Comparison of different types of ceramic hydroxyapatite for the chromatographic separation of plasmid DNA and a recombinant anti-rhesus d antibody. Bioseparation 9: 359368.

Hollander AP, Heathfield TF, Webber C, Iwata Y, Bourne R, Rorabeck C, Poole AR (1994) Increased damage to type ii collagen in osteoarthritic articular cartilage detected by a new immunoassay. J Clin Invest 93: 17221732.

Hutmacher DW, Schantz JT, Lam CX, Tan KC, Lim TC (2007) State of the art and future directions of scaffoldbased bone engineering from a biomaterials perspective. J Tissue Eng Regen Med 1: 245-260.

Karageorgiou V, Kaplan D (2005) Porosity of 3d biomaterial scaffolds and osteogenesis. Biomaterials 26: 5474-5491.

Khan Y, Yaszemski MJ, Mikos AG, Laurencin CT (2008) Tissue engineering of bone: Material and matrix considerations. J Bone Joint Surg Am 90 Suppl 1: 36-42.

Kotobuki N, Kawagoe D, Nomura D, Katou Y, Muraki K, Fujimori H, Goto S, Ioku K, Ohgushi H (2006) Observation and quantitative analysis of rat bone marrow stromal cells cultured in vitro on newly formed transparent $\beta$-tricalcium phosphate. J Mater Sci Mater Med 17: 3341.

Lin L, Chow KL, Leng Y (2009) Study of hydroxyapatite osteoinductivity with an osteogenic differentiation of mesenchymal stem cells. J Biomed Mater Res A 89: 326-335.

Liu Q, Cen L, Yin S, Chen L, Liu G, Chang J, Cui L (2008) A comparative study of proliferation and osteogenic differentiation of adipose-derived stem cells on akermanite and b-TCP- ceramics. Biomaterials 29: 4792-4799.

Milligan JR, Catz-Biro L, Archer MC (1987) Effect of phosphate concentration on the yield and purity of DNA separated from RNA by hydroxyapatite chromatography. J Chromatogr A 411: 481-485.

Rezwan K, Chen QZ, Blaker JJ, Boccaccini AR (2006) Biodegradable and bioactive porous polymer/inorganic composite scaffolds for bone tissue engineering. Biomaterials 27:3413-3431.

Salgado AJ, Coutinho OP, Reis RL (2004) Bone tissue engineering: State of the art and future trends. Macromol Biosci 4: 743-765.

Stevens B, Yang Y, Mohandas A, Stucker B, Nguyen KT (2008) A review of materials, fabrication methods, and strategies used to enhance bone regeneration in engineered 
bone tissues. J Biomed Mater Res B Appl Biomater 85: 573-582.

Watanabe T, Makitsuru K, Nakazawa H, Hara S, Suehiro T, Yamamoto A, Hiraide T, Ogawa T (1999) Separation of double-strand DNA fragments by highperformance liquid chromatography using a ceramic hydroxyapatite column. Anal Chim Acta 386: 69-75.

Wendt D, Marsano A, Jakob M, Heberer M, Martin I (2003) Oscillating perfusion of cell suspensions through three-dimensional scaffolds enhances cell seeding efficiency and uniformity. Biotechnol Bioeng 84: 205-214.

\section{Discussion with Reviewer}

Reviewer II: What would the authors recommend to fully validate their DNA quantification method, with regards to cell proliferation on ceramic constructs for bone tissue engineering?

Authors: The question addresses a critical aspect of characterization of engineered tissues, beyond the specific context of bone grafts. Indeed, the "full validation" of the proposed technique would require (i) a model where cell proliferation on 3D scaffolds is well defined and predictable, or (ii) a standard/direct method to quantify cell numbers on 3D scaffolds. However, to the best of our knowledge, none of these tools is currently available. In our work, we made use of different simplified models each with the own arbitrary assumptions - to try and circumvent the issue and to provide a higher level of confidence in the proposed validation. We acknowledge, however, as also discussed in manuscript, that this strategy only partially addressed the need of a completely reliable technique for DNA quantification in engineered or even native tissues. 